\title{
Competency Focused Engineering Education with Reference to IT Related Disciplines: Is the Indian System Ready for Transformation?
}

\author{
Sanjay Goel \\ Jaypee Institute of Information Technology \\ Noida, India
}

\section{Sanjay.goel@jiit.ac.in}

\section{Executive Summary}

The growth of the Indian IT industry has been of great interest to the international IT community. Nearly one third of fresh Indian engineering graduates are currently joining the IT industry irrespective of their specialization. The success of the Indian IT industry, however, has not been yet been leveraged for developing India as a preferred destination for engineering education, even in the disciplines related to information technology. Internationally, reforms in engineering education have a long but slow history. Last decade saw an increasing recognition of the need for the transformation of engineering education. Many accreditation agencies have even transformed their accreditation criteria in the last few years from a resource-based approach to an outcomebased approach.

This paper collates recommendations about core competencies for engineering graduates by NSF, National Academy of Engineers (NAE), Engineering Professor's Council (EPC), and authors like Felder, Bordogna, and others. It brings together the contemporary prescriptions of accreditation agencies in US, UK, Australia, Singapore, and Japan and also the recommendations made by ACM, IEEE, and other professional bodies with specific reference to various IT related disciplines. These accreditation agencies, NAE, IEEE, ACM, other professional agencies, and researchers have identified a number of core competencies as essential attributes of graduating engineers. There are great similarities in these recommendations that are now being increasingly used for enhancing the quality of engineering education. However, in order to further enhance the value of engineering education, it is proposed that ability to create wealth, self-sufficiency and a sense of well being through successful engineering enterprise, ability to assist others through philanthropic donation, and ability to work in multi-location teams may also be added to the list of recommended competencies, especially at the master's level. Based on Marzano's (1993) Dimensions of Learning, a three dimensional taxonomy of competencies has been proposed to cate-

Material published as part of this journal, either on-line or in print, is copyrighted by the Informing Science Institute. Permission to make digital or paper copy of part or all of these works for personal or classroom use is granted without fee provided that the copies are not made or distributed for profit or commercial advantage AND that copies 1) bear this notice in full and 2) give the full citation on the first page. It is permissible to abstract these works so long as credit is given. To copy in all other cases or to republish or to post on a server or to redistribute to lists requires specific permission and payment of a fee. Contact Publisher@InformingScience.org to request redistribution permission. gorize the recommended competencies along the three dimensions of attitudes and perceptions, productive habits of mind, and meaningful usage, extension, and acquisition of knowledge. This taxonomy is projected to have the flexibility to suit varying and emerging needs.

The paper then presents current accreditation criteria practiced by the National Board of Accreditation (NBA) of All India Council of Technical Education 
(AICTE), the accreditation agency in India. The accreditation criterion of NBA continues to be based on the traditional resource-based approach. Recommendations by National Association of Software and Service Companies (NASSCOM) and the Indian Government task force set up to examine the human resource challenge for IT and IT enabled Services (ITeS) sector have been briefly discussed. Both of these agencies have underrated some skills such as spoken English, creativity, and team working and have categorised them as desirable rather than necessary. The accreditation criteria of NBA and also some recommendations of NASSCOM and the Indian Government task force are not in alignment with the contemporary global perspectives on this issue.

The Indian engineering education sector can tremendously help the Indian IT industry to make a much larger contribution in higher value-added markets. It needs to focus on competence building by transforming its traditional teaching, learning, and assessment processes. This focus will also help in leveraging Indian IT industry's success for developing India as a preferred destination for engineering education at least in selected disciplines related to information technology. Further, faculty's unfamiliarity and inexperience with real life engineering projects as well as research on learning also need urgent attention in order to meet these objectives.

Keywords: Engineering education, engineering competencies, general professional competencies, attributes of engineer, skill shortage in IT industry.

\section{Introduction}

Engineering graduates of all disciplines have been the traditional pool for entry-level software engineering positions in the Indian IT industry. In order to meet the huge manpower requirement, many IT companies do not limit their choice to IT related disciplines for the recruitment of entrylevel software engineers. Often the freshmen recruitment process does not give special importance to specialization in computer science or allied areas. All engineering graduates are considered to be ready for a direct fit with the requirements of the IT industry (Task Force on Meeting the Human Resource Challenge for IT and IT enabled Services, 2003, p. 15). The core competencies developed in all engineering disciplines are considered to be sufficient and the companies rely more on their own finishing schools for specialized computer science and IT knowledge.

The growth of the Indian IT industry has been of great interest to the international IT community. Jalote (2001) summarizes its growth as follows:

"It started primarily as a subcontractor for technical manpower. Later it gradually shifted to doing complete parts or phases of projects, usually the later phases of coding and testing. From this, it matured to providing complete solutions offshore. Today most leading companies are operating in the high-end software services business. ... a large number of software companies matured to CMM level 4 or level $5 . . . "$

He then makes the following observations about people related factors that have contributed for this growth and maturity of IT industry in India:

"Due to the opportunities the software industry offers (a higher financial remuneration, overseas travel opportunities, respect in the society, etc.) best of the people started going to software (e.g. in the Indian Institutes of Technologies, the highest rankers in the entrance test choose to go to computer science.... this manpower is ambitious and wants improvement in the way the organization works." 
"Average age of the engineers is in 20 s and that of managers is late $20 \mathrm{~s}$ to early 30 s in the Indian software industry. The high growth rate ensures that people move up faster, keeping the average age of engineers and project managers low. This helps in various ways, one of them being that engineers and project managers are quite receptive to change, youth allows for hard work, positive approach to life, etc..."

"Engineers employed more than computer scientists. ... There is a very applied and intensive education program given to these engineers when they join the organization."

Nearly one third of fresh Indian engineering graduates are currently joining the IT industry irrespective of their specialization. In spite-of a huge increase in the engineering seats, especially in Information Technology related disciplines, estimates suggest that current manpower resources will not be sufficient to meet the aggressive growth targets. By 2009, based on current human resource supply trends (NASSCOM-KPMG, 2003, p. 19), it is estimated that there will be a shortfall of over 0.5 million personnel for the IT and ITeS sector. IT companies have responded to the projected manpower shortage and expedited freshmen recruitment process. Suddenly, without bringing any quality enhancement, engineering institutes are blessed with better placement opportunities. Engineering campuses are witnessing the new phenomenon of major IT companies undertaking a recruitment process in the pre-final year of study itself. Many IT companies have lowered down their recruitment standards to meet the numbers. Paradoxically, there is also large unemployment and underemployment amongst engineers in India. Attempts to overcome the manpower shortage without addressing the core issue of skill shortage are not likely to yield expected results. Hence, Indian engineering institutes have a new additional challenge of preparing students to sufficient maturity levels within the first five semesters and equipping them with the required core competencies.

Organizations and their clients have limited tolerance for inept performance. Often engineers engage directly with clients in complex interactions. Educators are expected to teach competencies that are relevant and enhance an organization's performance (Wilkinson, 2002). Stephen (1996) says, "Anyone not aware that this is a time of change in higher education is asleep at the helm." Universities around the world have become increasingly aware of the need to be able to demonstrate, in a quantifiable manner, the skills and attributes that their graduates are imbued with during their learning experience (Bullen, Waters, Bullen, \& de la Barra, 2004).

Reforms in engineering education have a long but slow history. Felder (1982, p. 6), remarked, "We teach primarily mechanics, and not reasoning methods; memorization and routine application, and not analysis, synthesis and evaluation. We don't encourage creativity and independence of thought, and in fact often do our best to discourage them." Sadly nothing much has changed on the ground. The community that is responsible for transforming the life style of the world has not yet transorfmed its own educational process. Felder and Brent (2004) reported on some recent studies that measured the intellectual growth of engineering students during their studies using Perry's model of epistemological development (Rapaport, 2004). It was observed that the engineering education failed to elevate a significant number of students to level 5 as per Perry's nine level models and the average growth after four years of college was only one level, with most of the change occurring in the last year. Another recent exploratory study has shown that the kind of activities that a typical engineering student is generally engaged in, does not help in enhancing creativity, critical thinking, and innovative problem solving (Goel S., 2004; Goel S. \& Sharda N., 2004). However, the last decade has seen an increasing recognition of the need for transformation. A certain section of policy makers, universities, accreditation agencies, and faculty members have made tremendous contributions to bring the much needed transformation. Many accredititation agencies have even transformed their accreditation criteria in the last few 
years. This is expected to drive an unprecedented transformation of instructional programs in responding institutes. This challenge can only be met by undertaking large scale research in engineering education. Recognising the need to re-engineer the engineering education a recent report Educating the Engineer of 2020 (National Academy of Engineers, 2005a, p. 54) suggests that "the engineering education establishment should endorse research in engineering education as a valued and rewarded activity for engineering faculty as a means to enhance and personalize the connection to undergraduate students, to understand how they learn, and to appreciate the pedagogical approaches that excite them."

The Indian engineering education sector can tremendously help the Indian IT industry to make a much larger contribution in higher value-added markets. It needs to focus on competence building by transforming its traditional teaching, learning, and assessment processes. This focus will also help it in developing India as a preferred destination for engineering education, at least in selected disciplines related to Information technology. We can use the following strategies proposed by Woods, Felder, Rugarcia, \& Stice (2000) to achieve this goal:

a. Identify the skills you wish your students to develop and communicate their importance to the students.

b. Use research, not personal intuition, to identify the target skills. Share some of the research with the students.

c. Make explicit the implicit behavior associated with successful application of the skills.

d. Provide extensive practice in the application of the skills, using carefully structured activities. Provide prompt constructive feedback on the students' efforts.

e. Encourage monitoring.

f. Encourage reflection.

g. Grade the process, not just the product.

h. Use a standard assessment and feedback form.

The literature review section first gives an overview of contemporary trends, recommendations, and findings related to core competencies by various professional agencies and accreditation boards. It also briefly examines the impact of these recommendations on curriculum. The current Indian situation is also briefly described. This is followed by a collation of a unified list of competencies. Some additional competencies are identified for inclusion in this list. A three dimensional taxonomy of these competencies is formulated using a grounded theory approach for analysis. In this context, the discussion section then argues for a reform in the Indian engineering education system.

\section{Literature Review}

\section{Multi-national Perceptions}

Bordogna (1997) quotes an NSF report (published in 1989) which identified integration, analysis, innovation and synthesis, and contextual understanding as key capabilities for engineering students. He also posits that the essence of engineering is the process of integrating different forms of knowledge to some purpose and an engineering student must experience the "functional core of engineering" - the excitement of facing an open-ended challenge and creating something that has never been. He proposes that a $21^{\text {st }}$ century engineer must have the capacity to: 
a. design, in order to meet safety, reliability, environmental, cost, operational, and maintenance objectives;

b. realize products;

c. create, operate, and sustain complex systems;

d. understand the physical constructs and the economic, industrial, social, political, and international context within which engineering is practiced;

e. understand and participate in the process of research; and

f. gain the intellectual skills needed for lifelong learning.

The National Academy of Engineers (NAE) suggests that the essence of engineering - the iterative process of designing, predicting performance, building, and testing — should be taught from the earliest stages of the curriculum, including the first year (National Academy of Engineers, 2005a, p. 53). Rugarcia, Felder,Woods, \& Stice (2000) proposed the following categories of necessary skills for engineers:

a. independent, interdependent and lifetime learning skills;

b. problem solving, critical and creative thinking skills;

c. interpersonal and teamwork skills;

d. communication skills;

e. self-assessment;

f. integrative and global thinking skills; and

g. Change-management skills.

Engineering is not just applied science; it is as much about process as it is about technical knowledge. An engineer's task involves conceiving and designing products, processes, and systems, and to predict their behavior using science. Scientists create models to understand natural phenomenon with known outcomes, whereas engineers create models to predict outcomes for systems. The use of heuristics distinguishes engineering methods from scientific methods. Many engineering faculty have never practiced engineering (Brown \& Rudolph, 2004). Curriculum's focus on content is disconnected from engineering practices (Goel, 2004; Goel \& Sharda, 2004). Dodridge (2003) classifies the attributes of engineers into two broad categories of knowledge and understanding and skills. Dodridge (2003) as well as Mason (1999) refer to a 1998 survey by EMTA (Engineering and Marine Training Authority) that identified practical skills, multiskilling, computer literacy, communication skills, management skills, personal skills, and problem solving skills as the most important skill deficiencies amongst engineers. Hoscette (2002) and Erlendsson (2001) have identified some workplace defects and leading causes of failures in engineering. As per their observation, the major concerns are passivity, non-responsiveness, uncritical thinking, technical incompetence, inept or poor communication skills, poor relations with the supervisor, inflexibility, poor and lax working habits, and too much independence.

Connor, Dench, \& Bates (2002) have identified new and specific technical skill, computer literacy and IT skills, multi-skilling and greater flexibility, the ability to deal with change, an ability to continue learning, re-skilling, and the greater importance of personal and generic skills as key themes in their assessment of skill trends. According to Engineering Professor's Council (EPC), United Kingdom, the key skills for engineering are communication skills, general IT user abilities, application of numbers, working with others, problem solving, and improving own learning and performance. It also identified the following primary competencies for engineers (The Engineering Professors Council, 2000): 
a. Transform existing systems into conceptual models.

b. Transform conceptual models into determinable models.

c. Use determinable models to obtain system specifications.

d. Select optimum specifications and create physical models.

e. Apply the results from physical models to create real target systems.

f. Critically review real target systems and personal performance.

Curriculum content is no longer the key as the accreditation agencies in many countries have transformed their accreditation criteria and standards in terms of core competencies. A major shift has taken place from input-based criteria to outcome-based approach. NAE in their vision report for 2020 (National Academy of Engineers, 2005a, pp53) recommends that engineering schools should vigorously exploit the flexibility inherent in the outcome-based accreditation approach to experiment with novel models for baccalaureate education. EC2000 criteria defined by Engineering Accreditation Commission (EAC) of Accreditation Board for Engineering and Technology (ABET), United States (ABET, 2004, pp. 2-3) recommends that engineering graduates must attain:

a. an ability to apply knowledge of math, science, and engineering;

b. an ability to design and conduct experiments, as well as analyze and interpret data;

c. an ability to design a system, component or process to meet desired needs;

d. an ability to function in multidisciplinary team;

e. an ability to identify, formulate and solve engineering problems;

f. an understanding professional and ethical responsibilities;

g. an ability to communicate effectively;

h. an understanding the impact of engineering solutions in a global and societal context.

i. a recognition of need and ability to engage in life-long learning;

j. a knowledge of contemporary issues; and

k. an ability to use the techniques, skills and modern engineering tools necessary for engineering practice.

Technology Accreditation Commission (TAC) of ABET prescribes the following abilities for the graduates of an engineering technology program (ABET, 2004, pp. 5, 7):

a. an appropriate mastery of the knowledge, techniques, skills and modern tools of their disciplines;

b. an ability to apply current knowledge and adapt to emerging applications of mathematics, science, engineering and technology;

c. an ability to conduct, analyze and interpret experiments and apply experimental results to improve processes;

d. an ability to apply creativity in the design of systems, components or processes appropriate to program objectives;

e. an ability to function effectively on teams;

f. an ability to identify, analyze and solve technical problems; 
g. an ability to communicate effectively;

h. a recognition of the need for, and an ability to engage in lifelong learning;

i. an ability to understand professional, ethical and social responsibilities;

j. a respect for diversity and a knowledge of contemporary professional, societal and global issues; and

k. a commitment to quality, timeliness, and continuous improvement.

Computing Accreditation commission (CAC) of ABET (ABET, 2004, p. 20) has proposed that the program outcomes for information technology and similarly named computing programs should minimally include the following abilities:

a. use and apply current technical concepts and practices in the core information technologies;

b. the ability to analyze, identify and define the requirements that must be satisfied to address problems or opportunities faced by organizations or individuals;

c. design effective and usable IT-based solutions and integrate them into the user environment;

d. assist in the creation of an effective project plan;

e. identify and evaluate current and emerging technologies and assess their applicability to address the users' needs;

f. analyze the impact of technology on individuals, organizations and society, including ethical, legal, security and global policy issues;

g. demonstrate an understanding of best practices and standards and their application;

h. demonstrate independent critical thinking and problem solving skills;

i. collaborate in teams to accomplish a common goal by integrating personal initiative and group cooperation;

j. communicate effectively and efficiently with clients, users and peers both verbally and in writing, using appropriate terminology; and

k. recognize the need for continued learning throughout their career.

United Kingdom Standards for Professional Engineering Competence (UK-SPEC) (Engineering Council, UK, 2003) has prescribed that an Incorporated Engineer must be able to:

a. use a combination of general and specialist engineering knowledge and understanding to apply existing and emerging technology;

b. apply appropriate theoretical and practical methods to design, develop, manufacture, construct, commission, operate and maintain engineering products, processes, systems, and services;

c. provide technical and commercial management;

d. demonstrate effective interpersonal skills ; and

e. demonstrate a personal commitment to professional standards, recognizing obligations to society, the profession and the environment.

UK-SPEC further refines the first two of these competencies for Chartered Engineers. A Chartered Engineer must be able to: 
a. use a combination of general and specialist engineering knowledge and understanding to optimize the application of existing and emerging technology; and

b. apply appropriate theoretical and practical methods to the analysis and solution of engineering problems.

The Institution of Engineers, Singapore (IES) (2004) defines the following competencies as part of its accreditation criteria of engineering programs:

a. apply knowledge of mathematics, science and engineering;

b. design and conduct experiments, analyze, interpret data and synthesize valid conclusions;

c. design a system, component, or process, and synthesize solutions to achieve desired needs;

d. identify, formulate, research through relevant literature review, and solve engineering problems reaching substantiated conclusions;

e. use the techniques, skills, and modern engineering tools necessary for engineering practice with appropriate considerations for public health and safety, cultural, societal, and environmental constraints;

f. communicate effectively;

g. recognize the need for, and have the ability to engage in life-long learning;

h. understand the impact of engineering solutions in a societal context and to be able to respond effectively to the needs for sustainable development;

i. function effectively within multi-disciplinary teams and understand the fundamental precepts of effective project management; and

j. understand professional, ethical and moral responsibility.

The Engineers Australia Accreditation Board (2005) has identified similar generic attributes that are as follows:

a. ability to apply knowledge of basic science and engineering fundamentals;

b. ability to communicate effectively; not only with engineers but also with the community at large;

c. in depth technical competence in at least one engineering discipline;

d. ability to undertake problem identification, formulation and solution;

e. ability to utilize a systems approach to design and operational performance;

f. ability to function effectively as an individual and in multi-disciplinary and multi-cultural teams, with the capacity to be a leader or manager as well as an effective team member;

g. understanding of social, cultural, global and environmental responsibilities of the professional engineers and the need of sustainable development;

h. understanding of the principles of sustainable design and development;

i. understanding of professional and ethical responsibilities and commitment to them; and

j. expectation of the need to undertake life long learning, and capacity to do so.

The Japan Accreditation Board for Engineering Education (JABEE) (2004) emphasizes the following competency set: 
a. the ability and intellectual foundation for considering issues from a global and multilateral viewpoint;

b. understanding of the effects and impact of technology on society and nature, and of engineers' social responsibilities (engineering ethics);

c. knowledge of mathematics, natural sciences and information technology, and the ability to apply such knowledge;

d. specialized engineering knowledge in each applicable field, and the ability to apply such knowledge to provide solutions to actual problems;

e. design abilities to organize comprehensive solutions to societal needs by exploiting various disciplines of science, engineering and information;

f. Japanese-language communications skills including methodical writing, verbal presentation and debate abilities, as well as basic skills for international communications;

g. the ability to carry on learning on an independent and sustainable basis; and

h. the ability to implement and organize works systematically under given constraints.

Successful Practices in International Engineering Education (SPINE) is a benchmark study focusing on the analysis of successful practices in engineering education in ten leading European and U.S. universities including MIT, CMU, and ETH Zurich. In the SPINE project, 543 professors of these universities, 1372 engineers and 145 managers of European and US companies were questioned. The study attempted to measure the perceived importance and assessment of fifty-one parameters on quality of education, teaching methods, engineering competencies, general professional skills, and aspects of reputation of institute through a quantitative analysis. In the final report (Bodmer, Leu, Mira, \& Rütter, 2002), the following observations have been made about respondents' perception of various engineering and general professional competencies:

a. The highest rated engineering competencies, both by professors and engineers were analysis/methodological skills, basic engineering proficiency, and problem solving skills. Engineers and Professors also agree on the lowest rated competencies: development know-how and practical engineering experience.

b. Engineers rated specialized engineering proficiency and research know-how as lesser important engineering competencies.

c. Very important general professional competencies include communication skills, English language skills, teamwork abilities, presentation skills, and leadership skills.

d. Medium importance was assigned to general professional competencies of social skills, ability to maintain and develop a broad general education, and management of business processes and administration.

e. General professional competencies of marketing, finance, and other language skills were rated as lesser important.

f. All three groups regarded law as least important general professional competency.

The US based Professional Aptitude Council (PAC) conducts a pre-employment aptitude examination for IT professionals. This has also been recently launched in India (Patrao, 2005). This examination consists of questions on nine parameters of problem solving, linear logic, mathematical ability, technical knowledge, applied technical skills, coding skills, creativity, work style, and personality composite. It identifies attention to detail, interpersonal skills, adaptabil-

ity/flexibility, persistence, sense of urgency, and creativity as IT related personality constructs. 
Listening, adaptability to new technology, time management, visualize/conceptualize, multitasking, business culture, "be the customer" mentality, constructive criticism, organizational skills, stress management, idea initiation, and project management are also highly valued skills in IT industry (Bailey \& Stefaniak, 2002). Chang (1998) and Erlendsson (2005) suggest additional competencies like knowing how to learn rapidly, ability to advocate and influence (persuasion), mentoring, decision making, and ability to manage complexity.

\section{Contemporary Recommendations of some International Profes- sional Societies}

The Joint Task Force on computing curricula of the IEEE Computer Society and the ACM has published several reports related to computing curricula. These reports make clear recommendations on this issue with reference to specific undergraduate programs in computer science, software engineering, computer engineering, and information technology. The final draft on computing curricula, 2001, suggested the following broad level characteristics of computer science graduates (The Joint Task Force on Computing Curricula, IEEE Computer Society and ACM, 2001):
a. System-level perspective.
b. Appreciation of the interplay between theory and practice.
c. Familiarity with common themes.
d. Significant project experience.
e. Adaptability.

This report also suggested the following general skills for computer science graduates:
a. Communication.
b. Teamwork.
c. Numeracy.
d. Self-management.
e. Professional development.

In 2004, the same task force has made specific recommendations about undergraduate degree programs in software Engineering (The Joint Task Force on Computing Curricula, IEEE Computer Society and ACM, 2004a). It suggests that graduates of an undergraduate software engineering program must be able to:

a. show mastery of the software engineering knowledge and skills, and professional issues necessary to begin practice as a software engineer;

b. work as an individual and as part of a team to develop and deliver quality software artifacts;

c. reconcile conflicting project objectives, finding acceptable compromises within limitations of cost, time, knowledge, existing systems, and organizations;

d. design appropriate solutions in one or more application domains using software engineering approaches that integrate ethical, social, legal, and economic concerns;

e. demonstrate an understanding of and apply current theories, models, and techniques that provide a basis for problem identification and analysis, software design, development, implementation, verification, and documentation; 
f. demonstrate an understanding and appreciation for the importance of negotiation, effective work habits, leadership, and good communication with stakeholders in a typical software development environment; and

g. learn new models, techniques, and technologies as they emerge and appreciate the necessity of such continuing professional development.

In their final report 'Curriculum guidelines for undergraduate degree programs in computer engineering' (The Joint Task Force on Computing Curricula, IEEE Computer Society and ACM, 2004a), the task force identified the following characteristics for computer engineering graduates:

a. System Level Perspective.

b. Depth and Breadth (of knowledge).

c. Design Experience.

d. Use of Tools.

e. Professional Practice.

f. Communication Skills.

In April 2005, the same task force has also proposed a draft computing curricula for information technology. This report suggests (The Joint Task Force on Computing Curricula, IEEE Computer Society and ACM, 2005) that pervasive themes for IT program outcome should be user centeredness and advocacy, information assurance and security, the ability to manage complexity, a deep understanding of information and communication technologies and their associated tools, adaptability, professionalism, and interpersonal skills. This report also recommends that an IT graduate must acquire the ability to:

a. use and apply current technical concepts and practices in the core information technologies;

b. analyze, identify and define the requirements that must be satisfied to address problems or opportunities faced by organizations or individuals;

c. design effective and usable IT-based solutions and integrate them into the user environment;

d. assist in the creation of an effective project plan;

e. identify and evaluate current and emerging technologies and assess their applicability to address the users' needs;

f. analyze the impact of technology on individuals, organizations and society, including ethical, legal and policy issues;

g. demonstrate an understanding of best practices and standards and their application;

h. demonstrate independent critical thinking and problem solving skills;

i. collaborate in teams to accomplish a common goal by integrating personal initiative and group cooperation;

j. communicate effectively and efficiently with clients, users and peers both verbally and in writing, using appropriate terminology; and

k. recognize the need for continued learning throughout their career.

In 2004, ACM, Association for Information Systems (AIS), and Association of Information Technology Professionals (AITP) published a joint report on 'Model curriculum and guidelines 
for undergraduate degree programs in information systems' and characterized this discipline as 'Technology-enabled Business Development.' They have divided the representative capabilities and knowledge expected for Information System graduates into the following categories (Gorgone et al., 2004, p. 14):

a. Analytical and critical thinking: organizational problem solving, ethics and professionalism and creativity.

b. Business fundamentals.

c. Interpersonal, communication and team skills.

d. Technology.

\section{Impact on Curriculum and Future Directions}

Recommendations of various accreditation agencies in US, UK, Singapore, Australia, and Japan have already affected educational programs not only in their respective countries, but also in other countries. Many universities have redefined their program objectives, delivery mechanism, and assessment systems to incorporate graduate attributes in teaching programs (Bell, 2000; Felder \& Brent, 2003). For example, Olin College of Engineering (National Academy of Engineers, 2005a, p. 105-106) has identified the following characteristics for their graduates:

a. Superb command of engineering fundamentals.

b. Broad perspective on the role of engineering in society.

c. Creativity to envision new solutions to problems.

d. Entrepreneurial skills to bring these visions to reality.

Macro level reforms are being realized through micro level redesigning of every course with a focus on fostering specific competencies (Bullen et al., 2004). Curriculum now gives more emphasis on design, practice, collaborative learning, humanities, social sciences and sustainable engineering (Turner, Li, \& Martinez, 2001). Faculty development programs have been organized to help them understand the underlying pedagogical issues (Bigio \& Schmidt, 1999). Learning theories and epistemological frameworks are being used to shift the focus of teaching, learning, and assessment processes on competency development (Campbell, Bunker, Hoffman, \& Iyer, 2004; Senini \& Nouwens, 2004).

The National Academy of Engineers (2005b) has identified the following attributes for engineers of 2020:
a. Strong analytical skills.
b. Practical ingenuity - skill in planning, combining, and adapting.
c. Creativity (invention, innovation, thinking outside the box, art).
d. Communication.
e. Business and management.
f. Leadership.
g. High ethical standards and professionalism.
h. Dynamism, agility, resilience, and flexibility.
i. Lifelong learners. 


\section{Indian Scenario}

One of nine Indian inventors included in the list of top 100 inventors under 35, Vikram Sheel Kumar, thinks that the biggest challenge an Indian student faces is finding the space to develop an independent mind ("9 Indians adorn", 2004). However, another inventor of Indian origin in the same list, Chaitali Sengupta thinks that engineering education in India is at the same level as the best in the world. Some of the senior industry managers in some industrial sectors feel concerned about lack of positive attitude, behavioral aspects, ability to cope up with challenges, sincerity, integrity, ethics, self-analysis, discipline, and independent thinking amongst fresh engineering graduates (Arya, 2005). It is very ironic that while 'availability of highly skilled manpower' has been identified as the most important factor that is driving the increasing momentum of R\&D offshoring/outsourcing industry in India; 'quality of higher education' has been identified as one of the main inhibitors (ValueNotes, 2004). This paradox needs some deeper analysis.

Table 1: Accreditation criteria and weightages defined by NBA, India for Diploma (Dip.), Undergraduate (UG) and Postgraduate (PG) engineering programs

\begin{tabular}{|c|c|c|c|c|}
\hline \multirow[t]{2}{*}{ No } & \multirow[t]{2}{*}{ Parameters } & \multicolumn{3}{|c|}{ Max. Marks } \\
\hline & & Dip. & $\mathbf{U G}$ & PG \\
\hline I & $\begin{array}{l}\text { Organization and governance } \\
\text { Planning and Monitoring, Recruitment Procedure \& its Effectiveness, } \\
\text { Promotional Policies/Procedure, Leadership, Motivational Initiatives, } \\
\text { Transparency, Decentralization and Delegation \& participation of faculty, } \\
\text { and Constitution of General council and bodies. }\end{array}$ & 30 & 80 & 50 \\
\hline II & $\begin{array}{l}\text { Financial resources, allocation and utilization } \\
\text { Budget allocated to the Institution and Utilization. } \\
\text { Budget allocated to the Department and Utilization. }\end{array}$ & 70 & 70 & 50 \\
\hline III & $\begin{array}{l}\text { Physical resources (central facilities) } \\
\text { Students' Hostel, Power back up, Reprographic facilities, Bank, Post Of- } \\
\text { fice, Counseling and Guidance, Language Lab., Medical Facility, Internet } \\
\text { Facility, Canteen, and Transport. }\end{array}$ & 50 & 50 & 50 \\
\hline IV & $\begin{array}{l}\text { Human resources: faculty and staff } \\
\text { Faculty } \\
\text { Numbers, Student Faculty Ratio, Cadre ratio, Average experience, faculty } \\
\text { retention, Turnover, Qualifications, Participation of faculty in Institutional } \\
\text { development/Departmental development/Academic matters/Students, } \\
\text { Development/Self growth, Implementation and Impact of Faculty Devel- } \\
\text { opment initiatives, Analysis and Follow-up of Performance appraisal, } \\
\text { Service rules, pay package, and incentives. } \\
\text { Support Staff (Technical/Administrative) } \\
\text { Numbers, Qualification/skills, and Skill up-gradation. }\end{array}$ & 200 & 200 & 200 \\
\hline V & $\begin{array}{l}\text { Human resources: students } \\
\text { Student admissions, Academic results, Performance in competitive ex- } \\
\text { aminations, and Placement. }\end{array}$ & 100 & 100 & 100 \\
\hline VI & $\begin{array}{l}\text { Teaching-learning processes } \\
\text { Delivery of syllabus, contents, Contents beyond the syllabus, Academic } \\
\text { calendar, Continuous evaluation procedure, Utilization of Laboratories, } \\
\text { Information access facilities, Student centric learning initiatives, Students } \\
\text { feedback. }\end{array}$ & 450 & 350 & 250 \\
\hline
\end{tabular}




\begin{tabular}{|c|c|c|c|c|}
\hline VII & $\begin{array}{l}\text { Supplementary processes } \\
\text { Extra \& co-curricular activities, Personality Development initiatives, Pro- } \\
\text { fessional society activities, Entrepreneurship Development, Alumni Inter- } \\
\text { action, Ethics, and Students Publications/Awards }\end{array}$ & 50 & 50 & 50 \\
\hline VIII & $\begin{array}{l}\text { Research \& development and interaction effort } \\
\text { Budget for in-house R\&D activities and its utilization, Aca- } \\
\text { demic/Sponsored/Industrial research and development, Publications and } \\
\text { Patents, Industry participation in developmental and student related activi- } \\
\text { ties, Continuing Education, Consultancy and Testing, Students' Project } \\
\text { Work. }\end{array}$ & 50 & 100 & 250 \\
\hline
\end{tabular}

The accreditation criteria defined by National Board of Accreditation (NBA) of All India Council of Technical Education (AICTE) (National Board of Accreditation, 2000), has not yet responded to above-mentioned contemporary models that emphasize carefully identified attributes and competencies based on national and global needs. One of the major objectives of NBA is to encourage the institutions to continually strive towards the attainment of excellence. However, it is still silent about the core competencies and continues to assess undergraduate and postgraduate engineering programs with respect to several inputs rather than focusing and encouraging the institutes to develop a set of carefully identified competencies. The details of parameters and their weightings as prescribed by NBA (National Board of Accreditation, 2000) are listed in Table 1.

A NASSCOM-KPMG study (NASSCOM-KPMG, 2003, p. 38), argues that key skills required by the industry are not met by the current educational system. It quotes the following observations from a World Bank Study on Science and Technology Manpower in India published in 2001:

a. Faculty lacks industry rigor, R\&D background and exposure to tools.

b. Students lack opportunity and encouragement for creative thinking.

c. Inflexible and rigid curriculum is not exposed to innovation/industry.

d. Teaching is exam oriented without focus on communication and problem solving skills.

e. Continuous evaluation is often not systematized.

f. Examinations are often memory based and encourage partial studying through ample choice.

NASSCOM-KPMG (2003, p. 36) and the Government of India Task Force (Task Force on Meeting the Human Resource Challenge for IT and IT enabled Services, 2003, p. 9) identify written English, logical reasoning, problem solving and numerical ability, programming skills, listening/empathy, assertiveness and confidence, integrity, values and discipline, sociability, dependability, and reliability as necessary skills for IT professionals. These reports identify spoken English, foreign language, accent understanding, comprehension/creativity, initiative/enthusiasm, team working, multitasking and time management, and motivation/drive as desirable skills.

\section{A Taxonomy of Core Competencies}

There are great similarities in the competency set identified by accreditation agencies of US, UK, Australia, Japan, and Singapore. Nine out of eleven competencies identified by ABET, US continue to reappear with some modifications in the competency list prescribed by accreditation agencies of all of these countries. However, some agencies have broadened the scope of some of these competencies to more comprehensive meaning-level. For example, JABEE has broadened ability to work in multidisciplinary teams into ability and intellectual foundation for considering 
issues from a global and multi-lateral viewpoint and also has put it at the first position of their list. I consider these competency lists to be ordered on importance as perceived by respective agency. While there are many similarities in the order proposed by these agencies, JABEE has ordered their list differently. It gives highest importance to the ability and intellectual foundation for considering issues from a global and multi-lateral viewpoint and understanding of the effects and impact of technology on society and nature, and of engineers' social responsibilities (engineering ethics). Using grounded theory approach for analysis, Table 2 gives a summarized and composite view of some of the most commonly distinguished and identified competencies by ABET, UK-SPEC, EA, JABEE, and IES.

Table 2: Comparative analysis of some common competencies distinguished and identified by some accreditation agencies

S.No

Competency

ABET UK- IES EA JABEE Average EC2000 SPEC

1 Ability to apply knowledge

2 Design skills

3 Problem solving skills

4 Technical competence

5 Ability to work in multidisciplinary teams

6 Sensitivity towards ethical and professional issues

7 Communication skills

8 Sensitivity towards global, societal, and environmental issues

$9 \quad$ Readiness for life-long learning
Position in the respective list

$\begin{array}{cccccc}1 & 2 & 1 & 1 & 3 & 1.6 \\ 3 & 2 & 3 & 5 & 5 & 3.6 \\ 5 & -- & 4 & 4 & 4 & 4.25 \\ 11 & 1 & 5 & 3 & 4 & 4.8 \\ 4 & 4 & 9 & 6 & 1 & 4.8 \\ 6 & 5 & 10 & 9 & 2 & 6.4 \\ 7 & 4 & 6 & 2 & 6 & 5 \\ 8 & 5 & 8 & 7 & 2 & 6 \\ 9 & 5 & 7 & 10 & 7 & 7.6\end{array}$

The following list puts these competencies as per the order of importance:

a. Ability to apply knowledge.

b. Design skills.

c. Problem solving skills.

d. Technical competence.

e. Ability to work in multidisciplinary teams.

f. Communication skills.

g. Sensitivity towards global, societal, and environmental issues.

h. Sensitivity towards ethical and professional issues.

i. Readiness for life-long learning. 
The following competencies are also identified as necessary either for engineers in general or specifically for engineers and professionals in IT related disciplines by various agencies and researchers:

a. System-level perspective (including Knowledge integration, consideration for multilateral viewpoint, and user centeredness).

b. Analytical skills (including investigative skills, critical thinking, numerical ability, attention to detail, visualize/conceptualize, research and experimentation skills).

c. Creativity and idea initiation.

d. Entrepreneurship, Decision-making, Project planning, and adaptability.

e. Persuasion skills, Mentoring skills, Persistence and Sense of urgency.

f. Sensitivity towards moral responsibilities and sustainability.

g. Knowledge of contemporary issues.

h. Ability to work in multicultural teams.

i. Listening

j. Adaptability and ability to multi-task

k. Organizational skills

1. "Be the customer" mentality.

$\mathrm{m}$. Project planning and management.

n. Stress management.

In order to enhance the value of engineering education for individuals, organizations as well as the society, I propose the following competencies for inclusion in the unified list of recommended competencies, especially for masters programs:

a. Ability to create wealth, self-sufficiency and a sense of well being through successful engineering enterprise.

b. Ability to assist others through philanthropic donations.

c. Ability to work in multi-locational teams.

Dimensions of Learning (Marzano, Pickering, \& McTighe, 1993), is a comprehensive model of learning and learning process. It structures the various aspects of learning along the following dimensions:

Dimension 1: Attitudes and perceptions.

Dimension 2: Acquire and Integrate Knowledge

Dimension 3: Extend and Refine Knowledge

Dimension 4: Use Knowledge Meaningfully

Dimension 5: Productive Habits of Mind

As per this model, all learning takes place against the backdrop of learners' attitudes and perceptions and their use of productive habits of mind. Dimension 4 subsumes dimension 3, which in turn subsumes dimension 2. This means that when learners extend and refine knowledge, they continue to acquire knowledge, and when they use knowledge meaningfully, they are still acquiring and extending knowledge. 
All above mentioned competencies belong to the dimensions of this model. Consequently, this model can be adapted for creating taxonomy of competencies that can accommodate all above mentioned as well as some other competencies that may be identified as important in future. Different accreditation agencies and also institutes can flexibly use this taxonomy. Considering acquisition, extensions, and meaningful usage of knowledge as levels of same dimension, all these are grouped into a single dimension. Figure 1 depicts the outline of this taxonomy.

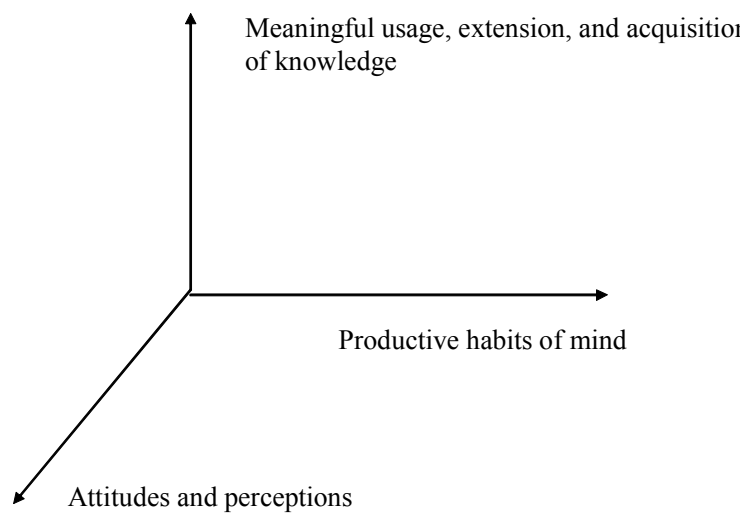

Figure 1: Three-dimensional framework of competencies

\section{Dimension 1: Attitudes and perceptions:}

Attitudes and perceptions affect a professional's ability to practice. The most important element of education should be to develop required attitudes and perceptions. The following list enumerates the recommended attitudes and perceptions, especially with reference to the requirements of IT related disciplines:

a. System-level perspective (including Knowledge integration, consideration for multilateral viewpoint, and User centeredness).

b. Ability to work in homogeneous, multidisciplinary, multi-locational and multicultural teams.

c. Sensitivity towards global, societal, environmental, moral, ethical and professional issues and sustainability.

d. "Be the customer" Mentality

e. Listening.

f. Readiness for lifelong learning.

g. Entrepreneurship.

h. Ability to assist others through mentoring and philanthropic donations.

i. Perseverance.

j. Sense of urgency and stress management.

k. Adaptability and ability to multi-task.

\section{Dimension 2: Productive habits of mind:}


The most effective professionals develop powerful habits of mind that enable them to think critically and creatively. The mental habits that are important for engineers, especially with reference to the requirements of IT related disciplines, are listed below:

a. Attention to detail.

b. Critical thinking.

c. Creativity and idea initiation.

d. Numerical ability.

\section{Dimension 3: Meaningful usage, extension, and acquisition of knowledge:}

Under the conditions of the right attitudes and perceptions, professionals use their productive habits of mind to acquire and integrate knowledge. Attitudes, perceptions, and productive habits help them to extend, refine and use knowledge for meaningful tasks. The following competencies are important with reference to the requirements of IT related disciplines:

a. Ability to apply knowledge.

b. Design skills.

c. Problem solving skills.

d. Technical competence.

e. Decision making skills

f. Analytical skills.

g. Research skills.

h. Constructive criticism

i. Experimentation skills.

j. Communication skills.

k. Project planning and management.

1. Organizational skills

m. Persuasion skills.

n. Mentoring skills.

o. Knowledge of contemporary issues.

p. Wealth creation skills.

\section{Discussion}

India is gradually emerging as a hub of the knowledge industry and aims to make much larger contributions. The Indian IT industry's success is not matched by its engineering education. India has not yet developed as a preferred engineering education destination for international students even for IT related disciplines. India is also trying to get provisional membership of Washington Accord signatories' consortium, which recognizes the substantial equivalency of accreditation systems of organizations holding signatory status, and the engineering education programs accredited by them. A comparison of the global perspective with resource-based accreditation process being followed by NBA reveals the urgency of a debate on defining essential competencies 
that Indian engineering education must develop. Systematic identification of core engineering and general professional competencies and a focus on developing these amongst our students will help in achieving these objectives.

The low quality of higher education is a matter of great concern, especially as India hosts approximately 400 universities with more than 1,300 engineering colleges producing nearly half a million engineering graduates every year. In terms of student's enrolment, four of its universities are amongst the world's ten largest universities. In spite of an impressively large university and engineering education system, none of the Indian universities have been included in the ranked list of the world's top 300 universities compiled by Shanghai Jiao Tong University (Institute of Higher Education, 2005). This ranking is based on several indicators of academic or research performance and gives $40 \%$ points to research output, $40 \%$ points to quality of faculty measured on the basis of Nobel prizes, Field medals, and highly cited researchers, $10 \%$ points to Quality of Education measured on the basis of Nobel Prizes and Fields Medals won by alumni, and $10 \%$ points to size of university. Only three Indian universities have been able to find a position in this list of the world's top 500 universities. Interestingly, Indian Institute of Sciences (IISc.), the top Indian university as per this list does not offer undergraduate programs.

In another ranked list of universities prepared by The Times Higher Education Supplement (THES) in 2004, the Indian Institutes of Technology (IIT) have been assigned a much higher rank of forty-one ("World university rankings," 2004). The evaluation criteria adopted by THES gives $50 \%$ points to peer review, $20 \%$ points to citation indices, $20 \%$ points to faculty/students ratio, and $10 \%$ points to international orientation of the university. THES has grouped seven independent IITs as a single university. This grouping is incorrect as all seven IITs are independent institutes with complete autonomy and academic system. As per THES report of 2004, IIT has scored eighteenth overall rank as per 'peer score', while its performance on all other parameters is very poor. As per 2005 partial report of THES, IIT (again wrong grouping) has got $3^{\text {rd }}$ highest peer score in the list of the world's top technology universities in spite of a very poor citation record ("World's top technological universities," 2005).

The impressive academic and professional achievements of IIT students, especially in Silicon Valley of California, have helped in creating an excellent international image for IITs. IITs succeed in attracting the best students who are selected through a highly competitive examination in which hundreds of thousands of students compete every year. However, all seven IITs put together produce a very tiny fraction (just little more than 1\%) of engineering graduates of India and a large number of them either leave India or go for higher management education after completing their undergraduate education. Interestingly, they also happen to be out of the jurisdiction of AICTE. The responsibility of preparing hundreds of thousands of engineers every year is shouldered by hundreds of other engineering institutes under various universities. The education system, infrastructure, academic processes, and standards followed in most of these institutes and universities are very different from IISc., or any of the IITs. Some amongst these have also been awarded the five star status by NBA. None of these institutes or technical universities is included in either of the above-mentioned ranked lists of top universities of the world. Hence, 'availability of highly skilled manpower' can be attributed to factors other than 'high quality of higher education.'

An exploratory study has shown (Goel, 2004; Goel \& Sharda, 2004) that the kind of activities that a typical engineering student in India is generally engaged in, does not help in enhancing creativity, critical thinking, and innovative problem solving. Further, there are many technical universities that have affiliated a very large number of AICTE approved engineering colleges. Some of these universities have affiliated more than hundred engineering colleges. All of these colleges under a single university follow a common syllabus and curriculum and have a common examination organized by the university. In an attempt to bring objectivity and impartiality, the assess- 
ment system is mostly dependent upon final written exams (up to $80 \%$ in theory subjects). This even defies the NBA's stated emphasis on continuous evaluation procedure. Every semester, thousands of engineering students of a university undertake a stereotype common final semester examination. Semester after semester, students are repeatedly tested at the lower cognitive levels of knowledge, comprehension, and application as per Bloom's taxonomy (Goel, 2004; Goel \& Shard., 2004). Higher cognitive thinking at the level of analysis, synthesis, and evaluation is not tested through these exams.

Most of Indian engineering institutes produce a very large number of engineering graduates without offering them enough opportunity and challenge for intellectual growth through their academic program. Consequently, the learning approach of many students for many subjects remains stagnated at reproduction directed level as per Vermunt's framework for classifying learning styles (Coffield, Moseley, Hall, \& Ecclestone, 2004). As part of teaching, learning, and assessment processes, students are repeatedly engaged in such activities that promote rote learning and conformity. The system does not make a focused effort to transform student's learning approach to application or meaning directed levels. A significant amount of creative energy of the bright and talented students remains untapped and unexpressed. A very large number of students are awarded $60 \%$ to $80 \%$ marks without giving them sufficient experience of design. The drop out rate from Indian engineering institutes is very low. Almost all admitted students easily manage to complete the program of study. Unfortunately, many large IT companies do not demand the institutes to transform their processes. They also indirectly encourage the institutes to do inflated marking as they short list only high achievers for recruitment process. It is sad that the existing short-listing criteria and recruitment process of many companies also fails to encourage institutes, faculty, as well as students to focus on developing design skills.

The teaching and assessment methods adopted by most of the Indian engineering colleges and universities focus on course coverage and knowledge acquisition with little scope for meaningful usage of knowledge for invention, decision making, experimental inquiry, investigation or problem solving. Indian universities have a great opportunity to become a key partner and contributor in actively forwarding the Indian IT industry's success story. India's engineering education system needs to take a proactive approach to harness and nurture the talent of potentially hardworking, disciplined, creative, and enterprising students.

As approximately one third of graduating engineers of India are now joining the IT industry annually, a special focus needs to be kept on this largest employer sector. The recommendations by NASSCOM-KPMG and also the Indian 'task force' (NASSCOM-KPMG, 2003 p. 36; Task Force on Meeting the Human Resource Challenge for IT and IT enabled Services, 2003, p. 9) are only first few steps in this direction. However, it opens up a debatable issue of underrating of some skills such as spoken English, creativity, and team-working as desirable rather than necessary. Their recommendations are not in perfect alignment with the contemporary global perspectives on this issue and need to be reviewed by further studies. Further, these reports do not substantiate their findings with any data. Even the process of arriving at these conclusions is not disclosed. Hence, it is not possible to validate their recommendations. There is a need to undertake and validate scientific studies for identification and ranking of core engineering and general professional competencies suitable to the needs of evolving the Indian IT industry. The SPINE project is a good model for undertaking such studies.

In order to promote the teaching of industry related practices, the accreditation boards in US, Australia, Singapore, and Japan include faculty's engineering and industrial experience as a critical parameter for evaluating faculty's competence (ABET, p. 3, 7; Engineers Australia Accreditation Board, 2005 p. 5; Institution of Engineers, Singapore, 2004 p. 15; JABEE, 2004 p. 15). The National Academy of Engineers (NAE) (2005a, p. 54-55) remarks that if engineering faculty, as a group, are to adequately prepare students for practice, then some population within that group 
must have credible experience in the world of non-academic practice. It makes a specific recommendation that colleges and universities should develop new standards for faculty qualifications, appointments, and expectations, for example, to require experience as a practicing engineer. The National Board of Accreditation's (NBA) criterion related to faculty competence does not make any specific mention of such a requirement. Institutes do not make any special effort to attract engineers with such experience as members of their faculty. With the result, only a very few engineering educators in India have practical engineering experience. This creates a serious disconnect between industrial requirements and engineering education.

NBA has identified the teaching learning process as the most important parameter amongst eight parameters. However, its interpretation of this parameter is very superficial and oversimplified. A much deserved large-scale awareness, attention and research on this issue is surprisingly missing from the agenda of academic discourse. Not only have most of engineering academics never practiced engineering, but they also continue to teach for decades without ever exposing themselves to the vast research and literature in SOTL (Scholarship of Teaching and Learning). The professional practices they use and apply as teachers inside their classrooms develop through their own practice and application of their common sense without any systematic training or research based improvement (Goel, 2006). NAE (National Academy of Engineers, 2005a, p. 54) also recommends that changes in engineering learning experiences involving curricula, pedagogies, and support services should be based on research on learning. Unfortunately, research and faculty development programs in the areas of curriculum development, material development, and pedagogical skills are almost missing from the agenda of Indian engineering educators. Consequently, Felder's question, "Does engineering education have anything to do with either one" (Felder, 1982 ) is as much applicable to India's engineering education system even today. Considering the huge size of this system, the implications of this disconnect are much more serious. Without addressing these issues, the Indian engineering education system will not be able to leverage the benefits of international goodwill that the Indian IT industry has generated for itself and hence, India's potential as a preferred international destination for engineering education will remain unknown and untapped.

It is clear that the current Indian accreditation criterion needs modification so that it can help to promote excellence in engineering education. As IT educators, there is a great opportunity to practice what we preach. We need to apply some the following well-known principles of software engineering to curriculum design and instruction delivery:

a. Errors made during requirement analysis phase are costliest to correct.

b. All stakeholders have to be actively involved for successful requirement analysis.

c. Often the non-functional requirements are even more important than functional requirements.

d. In the absence of proper requirement analysis, the development team is always in a firefighting mode and is replacing and adding patches.

Accreditation agency, universities and engineering institutes are strongly encouraged to undertake serious requirement analysis for curriculum design by involving all stakeholders. The Indian IT industry now has sufficient maturity and international experience. Besides providing a whole range of low-end technical services, it is also working at the cutting edge of technology. It has matured to the most competitive levels of technical proficiency, project management, and quality consciousness. Indian engineering curriculum designers will immensely benefit from deeper inputs from this industry. Often this input is received at very superficial levels, and the focus is on different topics and subjects rather than competencies. Before taking the simplistic approach of prescribing the course structure and contents, it is important to identify the competencies we need 
to develop in our engineering graduates. Based on such a requirement analysis, through their recommendations and guidelines, the accreditation agency can play a very positive role in motivating institutes to pay attention to the development and strengthening of required competencies amongst their students. Argued competency identification then has to be matched with transformation of teaching, learning, and assessment processes. Technical universities and engineering institutes have a challenge as well as an opportunity to play a more proactive role by focusing their curriculum on development of carefully identified competencies. Faculty's awareness about current trends of competency focused engineering education and their commitment to remove the weaknesses of existing system is a precondition for this transformation.

\section{Conclusion}

Accreditation agencies of US, UK, Australia, Japan, and Singapore have transformed their accreditation process from the traditional resource-based approach to outcome-based approach. Competencies such as ability to apply knowledge, design skills, problem solving skills, technical competence, ability to work in multidisciplinary teams, communication skills, sensitivity towards global, societal, and environmental issues, and sensitivity towards ethical and professional issues, and readiness for lifelong learning have been identified as necessary. These accreditation agencies, IEEE, ACM, NAE, and other professional agencies have further identified a large number of other competencies such as systems level perspective, analytical skills, critical and creative thinking, as essential.

In order to further enhance the value of engineering education, it is proposed that ability to create wealth, self-sufficiency and a sense of well being through successful engineering enterprise, ability to assist others through philanthropic donation, and ability to work in multi-location teams may also be added to the list of recommended competencies, especially at the master level. Further, based on Marzano's (1993) Dimensions of Learning, a three dimensional taxonomy of competencies has been proposed to categorize the recommended competencies along the three dimensions of attitudes and perceptions, productive habits of mind, and meaningful usage, extension, and acquisition of knowledge. This taxonomy is projected to have the flexibility to suit different and emerging needs.

Indian accreditation system continues to follow the traditional resource-based approach. The Indian accreditation agency, universities and engineering institutes are strongly encouraged to undertake serious requirement analysis for curriculum design by involving all stakeholders. Further, faculty's unfamiliarity and inexperience with real life engineering projects as well as research on learning also need urgent attention. These suggestions, if implemented, will vastly improve the quality of engineering education in India. This can augment the Indian IT success story, and make India a preferred destination for engineering education.

Future research will focus on systematic analysis of perceptions of a representative sample of experts from the Indian IT industry about importance of core engineering as well as general professional competencies using the SPINE model. The proposed taxonomy of competencies will be validated. An empirical survey will be undertaken to prepare a catalog of successful practices for promotion of identified competencies.

\section{Acknowledgements}

The author would like to acknowledge the contributions of the editor and unknown reviewers, whose thoughtful suggestions have been very helpful. The ongoing interest and critique of Professor M. N. Faruqui, Professor S. K. Kak, Dr. Mukul K. Sinha, Mr. H. S. Dagar, Professor 
Ashok Subramanian, Professor A. B. Bhattacharyya, Prof. J. P. Gupta, Mr. S. D. Gupta, Ms. N. Mathur, and Ms. S. Dev has also been of significant assistance.

\section{References}

9 Indians adorn MIT's top 100 innovators list. (2004, November 8). The Times of India. Retrieved October 11, 2005 from http://timesofindia.indiatimes.com/articleshow/msid-916533,curpg-2, fright-0, right$\underline{0 . \mathrm{cms}}$

ABET (Accreditation Board for Engineering and Technology). (2004). Criteria for accrediting engineering programs: Effective for evaluations during the 2005-2006 accreditation cycle. Retrieved October 31, 2005 from http://www.abet.org/Linked Documents-UPDATE/Criteria and PP/05-06-EAC Criteria.pdf

Arya, S. P. (2005). JIIT-placement e-group [email posting]. Retrieved October 15, 2005 from http://groups.yahoo.com/group/placement-jiit/message/957

Bailey, J. L. \& Stefaniak, G. (2002). Preparing the information technology workforce for the new millennium. ACM SIGCPR Computer Personnel, 20(4), 4-15.

Bell, T. E. (2000). Proven skills: The new yardstick for schools. IEEE Spectrum, September, pp. 63-67. Retrieved on October 14, 2005 from http://home.att.net/ trudy.bell/abet0900.pdf

Bigio, D. \& Schmidt, J. (1999). A workshop of faculty development based on the underlying pedagogical issues of ABET EC 2000. $29^{\text {th }}$ ASEE/IEEE Frontiers in Education Conference, pp 12a1-5 - 12a1-9. Retrieved October 14, 2005 from http://fie.engrng.pitt.edu/fie99/papers/1039.pdf

Bodmer, C., Leu, A., Mira, L. \& Rütter, H. (2002). SPINE: Successful practices in international engineering education (pp 92-102). Retrieved October 14, 2005 from http://www.ingch.ch/pdfs/spinereport.pdf

Bordogna, J. (1997). Making connections: The role of engineers and engineering education. The Bridge, $27(1$ - Spring). Retrieved October 15, 2005 from http://www.nae.edu/nae/bridgecom.nsf/weblinks/NAEW-4NHMPY?OpenDocument

Brown, A. \& Rudolph, H. (2004). Educating engineers for the $21^{\text {st }}$ century. Proceedings of $15^{\text {th }}$ Annual AAEE Conference (pp. 106-113).

Bullen, F., Waters, D., Bullen, M. \& de la Barra, B. L. (2004). Incorporating and developing graduate attributes via program design. $15^{\text {th }}$ Annual AAEE Conference (pp. 29-39).

Campbell, D., Bunker, J., Hoffman, K. \& Iyer, R M. (2004). Processes in distilling course capability profiles. 15 $5^{\text {th }}$ Annual AAEE Conference (pp. 57-67).

Chang, I. F. (1998). Challenges to engineering education in the 21 st century. Retrieved October 15, 2005 from http://www.hi.is/ joner/eaps/wh enedx.htm

Coffield, F., Moseley, D., Hall, E. \& Ecclestone, K. (2004). Learning styles and pedagogy in post-16 learning: A systematic and critical review (pp 103-104) Retrieved October 20, 2005 from www.lsda.org.uk/files/PDF/1543.pdf

Connor, H., Dench, S. \& Bates, P. (2002). Skills dialogue: An assessment of skill needs in engineering, Department for Education and Employment, UK. Retrieved October 15, 2005 from http://www.employment-studies.co.uk/summary/summary.php?id=dfeesd2

Dodridge, M. (2003). Convergence of engineering higher education - Bologna and Beyond. Proceedings of the Ibero-American Summit on Engineering Education. Retrieved October 14, 2005 from http://www.univap.br/iasee/anais/trabalhos/Dodridge-Convergence\%20of $\% 20$ Engineering $\% 20$ Higher \%20Education1.pdf

Engineers Australia Accreditation Board. (2005). Engineers Australia policy on accreditation of professional engineering programs (pp. 3 \& 5). Retrieved October 14, 2005 from http://www.ieaust.org.au/membership/res/downloads/P020\%20Engineers\%20Australia\%20Policy\%20 on $\% 20$ Accreditation $\% 20 \mathrm{of} \% 20$ Professional $\% 20$ Engineering $\% 20$ Programs.pdf 
Engineering Council, UK. (2003). UK-SPEC standard for chartered engineers \& incorporated engineers (pp. 5-11). Retrieved October 14, 2005 from http://www.engc.org.uk/documents/CEng_IEng_Standard.pdf

The Engineering Professors Council. (2000). The EPC engineering graduate output standards, EPC Occasional Paper Number 10 (pp. 7-8). Retrieved October 15, 2005 from http://www.engprofc.ac.uk/op/op10.pdf

Erlendsson, J. (2001). Engineering graduates: Desirable characteristics. Retrieved October 15, 2005 from http://www.hi.is/ joner/eaps/ds chare.htm

Erlendsson, J. (2005). Systemic engineering education reform. Retrieved October 29, 2005 from http://www.hi.is/ joner/eaps/wh_enedx.htm

Felder, R. M. (1982). Does engineering education have anything to do with either one: Toward a systems approach to training engineers (p. 6). R.J. Reynolds Industries Award Distinguished Lecture Series, North Carolina State University. Retrieved October 16, 2005 from http://www.ncsu.edu/felderpublic/Papers/RJR\%20Monograph.pdf

Felder, R. M. \& Brent, R. (2003). Designing and teaching courses to satisfy the ABET engineering criteria. Journal of Engineering Education, January, 7-25. Retrieved October 14, 2005 from http://www.ncsu.edu/felder-public/Papers/ABET_Paper_(JEE).pdf

Felder, R. M. \& Brent, R. (2004). The intellectual development of science and engineering students Part 1. Models and challenges. Journal of Engineering Education, 93(4), 269-277. Retrieved October 14, 2005 from http://www.ncsu.edu/felder-public/Papers/IntDev-I.pdf

Goel, S. (2004). What is high about higher education? Examining engineering education through Bloom's taxonomy. The National Teaching \& Learning Forum, 13(4), 1-5. Retrieved October 14, 2005 from http://www.ntlf.com/FTPSite/issues/v13n4/v13n4.pdf

Goel, S. (2006). Do Engineering Faculty Know What's Broken? The National Teaching \& Learning Forum, 15(2).

Goel, S. \& Sharda, N. (2004). What do engineers want? Examining engineering education through Bloom's taxonomy. Proceedings of 15th Annual AAEE Conference (pp. 173-185). Retrieved from http://www.engineering.usu.edu/ete/documents/becker/learning/Learning_Styles/BloomandEngineerin g.pdf

Gorgone, J. T., Davis, G. B., Valacich, J. S., Topi, H., Feinstein, D. L. \& Longenecker, Jr., H. E.. (2004). Model curriculum and guidelines for undergraduate degree programs in information systems. Retrieved October 14, 2005 from http://www.acm.org/education/is2002.pdf

Hoscette, J. (2002). Leading causes of failures in engineers - Career development. Retrieved October 15, 2005 from http://www.hi.is/ joner/eaps/es_1023f.htm

Institution of Engineers, Singapore (IES). (2004). Engineering Accreditation Board: Accreditation manual (pp. 13-15). Retrieved October 15, 2005 from http://www.ies.org.sg/eab/accr_man.pdf

Institute of Higher Education, Shanghai Jiao Tong University. (2005). Academic ranking of world universities - 2005. Retrieved October 15, 2005 from http://ed.sjtu.edu.cn/rank/2005/ARWU2005.xls

JABEE (Japan Accreditation Board for Engineering Education). (2004). Criteria for accrediting Japanese engineering (pp. 1, 15). Retrieved October 15, 2005 from http://www.jabee.org/english/OpenHomePage/e criteria2004-2005(2).pdf

Jalote, P. (2001). The success of the SPI efforts in India. Software Quality Professional, 3(2). Retrieved October 15, 2005 from http://www.cse.iitk.ac.in/users/jalote/papers/IndiaSPI.pdf

The Joint Task Force on Computing Curricula, IEEE Computer Society and ACM. (2001). Characteristics of CS graduates, Computing curricula (pp. 62-65). Retrieved October 15, 2005 from http://www.computer.org/portal/cms_docs_ieeecs/ieeecs/education/cc2001/cc2001.pdf 
The Joint Task Force on Computing Curricula, IEEE Computer Society and ACM. (2004a). Software Engineering 2004: Curriculum guidelines for undergraduate degree programs in software engineering (pp. 15-16). Retrieved October 15, 2005 from http://sites.computer.org/ccse/SE2004Volume.pdf

The Joint Task Force on Computing Curricula, IEEE Computer Society and ACM. (2004b). Curriculum guidelines for undergraduate degree programs in computer engineering. Final report (p. 7). Retrieved October 15, 2005 from http://www.acm.org/education/CE-Final Report.pdf

The Joint Task Force on Computing Curricula, IEEE Computer Society and ACM. (2005). Characteristics of IT graduates, computing curricula: Information Technology Volume (pp. 38-40). Retrieved October 15, 2005 from http://www.acm.org/education/IT_2005.pdf

Marzano, R. J., Pickering, D. \& McTighe, J. (1993). Introduction, assessing student outcomes: Performance assessment using the dimensions of learning model. Retrieved October 26, 2005 from Association for Supervision and Curriculum Development (ASCD) http://www.ascd.org/portal/site/ascd/template.chapter/menuitem.b71d101a2f7c208cdeb3ffdb62108a0c/ ?chapterMgmtId=a740a2948ecaff00VgnVCM1000003d01a8c0RCRD

Mason, G. (1999). Engineering skills formation in Britain: Cyclical and structural issues (p. 9). Retrieved October 15, 2005 from http://www.etechb.co.uk/reslib/Engineering\%20Skills\%20Formation\%20in\%20Britain\%20$\% 20$ Cyclicale $\% 20$ and $\% 20$ Structural\%20Issues.doc

National Academy of Engineers. (2005a), Educating the engineer of 2020: Adapting engineering education to the new century (pp. 53-55, 105-106). Washington, DC: The National Academies Press. Retrieved October 18, 2005 from http://www.nap.edu/catalog/11338.html

National Academy of Engineers. (2005b). The engineer of 2020: Visions of engineering in the new century (pp. 53-57). Washington, DC: The National Academies Press. Retrieved October 19, 2005 from http://www.nap.edu/catalog/10999.html

NASSCOM-KPMG. (2003). Strengthening of HR for the IT services and ITES sector (pp. 19, 36 \& 38).

National Board of Accreditation. (2000). AICTE, Accreditation parameter: Criteria and weightages. Retrieved October 15, 2005 from http://www.nba-aicte.ernet.in/parameter.doc

Patrao, M. (2005, April 28). Testing tenacity of IT students. Deccan Herald. Retrieved October 15, 2005 from http://www.deccanherald.com/deccanherald/apr282005/dheducation2022552005426.asp

Rapaport, W. J. (2004). William Perry's scheme of intellectual and ethical development. Retrieved October 27, 2005 from http://www.cse.buffalo.edu/ rapaport/perry.positions.html

Rugarcia, A., Felder, R. M., Woods, D. R. \& Stice, J. E. (2000). The future of engineering education-I: A vision for a new century. Chemical Engineering Education, 34(1), 16-25. Retrieved October 16, 2005 from http://www.ncsu.edu/felder-public/Papers/Quartet1.pdf

Senini, S. \& Nouwens, F. (2004). A design framework for developing technical competence professional skills and identity. 15th Annual AAEE Conference (pp. 47-56).

Stephen, W. D. (1996). National and global imperatives in engineering education. Australasian Journal of Engineering Education, 7(1). Retrieved October 15, 2005 from http://elecpress.monash.edu.au/ajee/vol7nol/director.htm

The Task Force on Meeting the Human Resource Challenge for IT and IT enabled Services. (2003). Report and recommendations, Ministry of Communication and Information Technology, Government of India (pp. 9, 15).

Turner, C. D., Li, W. \& Martinez, A. (2001). Developing sustainable engineering across a college of engineering. Proceedings of American Society for Engineering Education Annual Conference \& Exposition. Retrieved October 11, 2005 from www.utep.edu/green/papers/asee2001.pdf

ValueNotes. (2004), R\&D outsourcing - The India edge: Key insights and success factors. Retrieved October 15, 2005 from http://www.researchandmarkets.com/reportinfo.asp?report_id=224141\&t=e\&cat_id=2 
Wilkinson, J. (2002). Re-engineering competency-based education through the use of a multimedia CDROM: A matter of life or death. Industry and Higher Education, 16(4), 261-265. Rretrieved October 15, 2005 from http://www.ingentaconnect.com/content/ip/ihe/2002/00000016/00000004/art00008

Woods D.R., Felder R.M., Rugarcia A. \& Stice J.E. (2000), The future of engineering education. III. Developing Critical Skills. Chemical Engineering Education, 34(2), 108-117. Retrieved October 16, 2005 from http://www.ncsu.edu/felder-public/Papers/Quartet3.pdf

World university rankings-2004. (2004). The Times Higher Education Supplement. Retrieved October 11, 2005 from http://www.thes.co.uk/downloads/rankings/world-rankings-16pages.pdf

World's top technological universities. (2005). The Times Higher Education Supplement. Retrieved October 11, 2005 from http://www.thes.co.uk/statistics

\section{Biography}

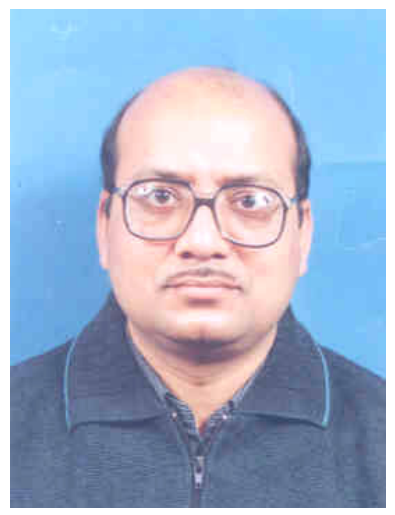

Sanjay Goel is Associate Professor and Head of the Department of Computer Science \& Engineering/Information Technology at Jaypee Institute of Information Technology (JIIT), Noida, India. He earned his M.Tech. (Computer Technology) from IIT Delhi, and his B.E (Hons.) (Electrical and Electronics Engg.) and M.Sc. (Hons.) (Physics) from BITS, Pilani. He has nearly 20 years of mixed experience in teaching, software development, and interactive multimedia content creation. Prior to joining JIIT, he was Director (Multimedia) at Indira Gandhi National Centre for the Arts (IGNCA). He has been a faculty member at Delhi University for more than a decade, and has also worked at National Informatics Centre, New Delhi. He enjoys inter-disciplinary work and his professional interests include Learning Sciences \& Technology, Software Design, Visual Computing, Multimedia, and Cultural Heritage Informatics. 